\title{
Paleomagnetism and fission-track ages of Oki-Dogo Island in Southwest Japan
}

\author{
Takeshi Kojima ${ }^{1}$, Makoto Okada ${ }^{1}$, Hiroto Ohira ${ }^{2}$, Katsuyasu Tokieda ${ }^{2}$, Hiroaki Komuro $^{2}$, and Kazuo Amano ${ }^{1}$ \\ ${ }^{1}$ Department of Environmental Sciences, Ibaraki University, Mito 310-8512, Japan \\ ${ }^{2}$ Department of Geoscience, Shimane University, Matsue 610-8504, Japan
}

(Received March 21, 2000; Revised September 29, 2000; Accepted September 30, 2000)

\begin{abstract}
Zircon fission-track (F.T.) ages and paleomagnetic directions were measured on the Neogene series of the OkiDogo Island. The results of F.T. dating on the the Tokibariyama Formation show ages of $23.7 \pm 1.3$ and $20.0 \pm 2.3$ Ma, indicating the early Early Miocene. Paleomagnetic measurements of the Tokibariyama, Kori Formations (24$17 \mathrm{Ma})$ and the Oki Trachyte-Rhyolite $(6.8 \mathrm{Ma})$ were done to reveal the movement of Oki-Dogo Island during the Japan Sea opening. The Tokibariyama and Kori Formations show an average declination of $39.9^{\circ}$. The Oki Trachyte-Rhyolite has the same average geomagnetic direction as the present day value. These results show that a clockwise rotation of $40^{\circ} \pm 15^{\circ}$ of the Oki-Dogo Island occurred between 17 and $6.8 \mathrm{Ma}$ which is similar to the main land of southwest Japan.
\end{abstract}

\section{Introduction}

The debate on the differences in the paleomagnetic declinations of the Japanese Islands was initiated by Kawai et al. (1961). They proposed a Cretaceous-Tertiary tectonic hypothesis that the present bow-shaped Japanese islands were formed by bending. Otofuji et al. (1985) reported paleomagnetic data indicating a counterclockwise rotation of $47^{\circ}$ of northeast Japan and a clockwise rotation of $56^{\circ}$ of southwest Japan between 21 and 11 Ma. Otofuji et al. (1991) concluded $80 \%$ of the rotation of southwest Japan occurred at around $15 \mathrm{Ma}$ during a period less than only 2 m.y. On the other hand, deep sea drilling in the Japan Sea provided a result showing that the ocean floor of the Japan Sea formed between 28 and $18 \mathrm{Ma}$ (Tamaki et al., 1992). Jolivet et al. (1995) proposed the idea that a part of the $50^{\circ}$ clockwise rotation of southwest Japan was due to internal deformation of the rotating blocks with second order dominoes. The debate on the timing and the mechanism of the opening of the Japan Sea is still continuing.

The Oki-Dogo Island, where a Neogene series is widely distributed covering the Oki Metamorphic and Granitic Rocks unconformably, is located in the southwestern part of the Japan Sea (Fig. 1). The Tokibariyama, Kori, and Kumi Formations, which were formed during the Japan Sea opening, mainly consist of calc-alkaline volcanic rocks and fluvial-shallow marine deposits (Yamasaki, 1992). The Oki Trachyte-Rhyolite, which was formed after the Japan Sea opening, is distributed in the western part of Oki-Dogo Island. This series is, therefore, a good object to test the model of the Japan Sea opening. Ito (1970) reported paleomagnetic data of the Oki-Dogo Island, however this data is insufficient to discuss the movement of the Oki-Dogo Island because all of the paleomagnetic samples are after Late Miocene. We

Copy right (c) The Society of Geomagnetism and Earth, Planetary and Space Sciences (SGEPSS); The Seismological Society of Japan; The Volcanological Society of Japan; The Geodetic Society of Japan; The Japanese Society for Planetary Sciences. carried out paleomagnetic studies and fission-track (F.T.) dating of the series to clarify the timing of the movement of the Oki-Dogo Island related to the Japan Sea opening.

\section{Geological Setting}

Figures 1 and 2 show the Neogene stratigraphy and the geological map of the study area, respectively. The Neogene series consists of the Tokibariyama, Kori, Kumi, and Tsuma Formations, Oki Trachyte-Rhyolite, and Tsuzurao Quarts Rhyolite, in ascending order. We describe in detail the stratigraphy and the geological structures of the Tokibariyama, Kori, Kumi Formations and the Oki TrachyteRhyolite, from which samples were collected for F.T. dating and paleomagnetism.

\subsection{Stratigraphy}

The Tokibariyama Formation is divided into the lower and upper members according to lithology (Yamasaki, 1992). The lower member is in fault contact with the basememt and partly unconformably overlies the basement. It is mainly composed of rhyolitic pyroclastic rocks and also contains andesite lavas and mudstone. The upper member is mainly composed of andesite lavas and intercalates andesitic pyroclastic rocks, dacite lavas and dacite pyroclastic rocks. The F.T. ages (26.0 $\pm 4.2 \mathrm{Ma}$; Kano and Nakano, 1985) of zircon and the K-Ar age $(19.7 \pm 0.6 \mathrm{Ma}$; Tainosho et al., 1991) of the potassium feldspar of the younger granite, which intruded into the Tokibariyama Formation (Yamasaki, 1991), show that the Tokibariyama Formation was deposited after the Oligocene (Yamasaki, 1992).

The Kori Formation is divided into the Koji Tuff, Ohzuku Conglomerate, Kori Basalt, Nagu Volcanic, and Togo Basalt Members (Yamasaki, 1991, 1992). This formation unconformably overlies the Tokibariyama Formation. The Kori Basalt, Nagu Volcanic and Togo Basalt Members are contemporaneous heterogeneous facies with the Koji Tuff and the Ohzuku Conglomerate Members (Yamasaki, 1992). The 


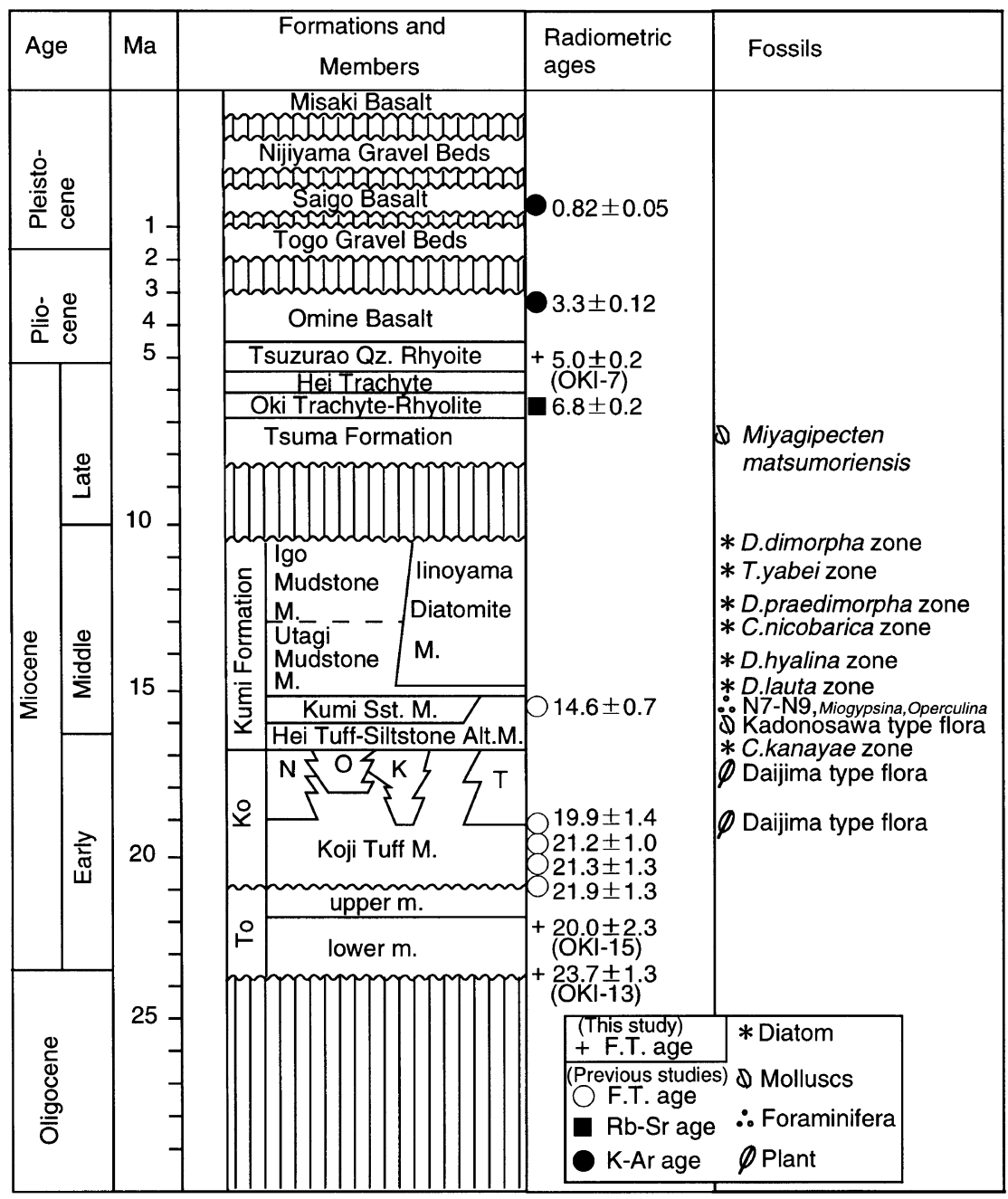

Fig. 1. Schematic columnar section. To: Tokibariyama Formation, Ko: Kori Formation, N: Nagu Volcanics Member, O: Ohzuku Conglomerate Member, K: Kori Basalt Member, T: Togo Basalt Member, Alt.: Alternation, M.: Member, Sst.: Sandstone, Qz.: Quartz. After Iwata et al. (1988), Kaneoka et al. (1977), Kojima et al. (1995), Okubo and Takayasu (1980), Sawada et al. (1999), Yamasaki (1992), Yamasaki and Gansawa (1989), and Yokota (1984).

Kori Basalt Member is distributed in the northern part of the Oki-Dogo Island and composed of basalt lavas, basaltic pyroclastic rocks, and volcanic conglomerate. Most of these basalt lavas are auto-brecciated. The Nagu Volcanic Member is distributed on the west coast of the Oki-Dogo Island and composed of basalt lavas, basaltic pyroclastic rocks, volcanic conglomerate and volcanic sandstone. The Togo Basalt Member is distributed on the east coast of the Oki-Dogo Island and composed of auto-brecciated clinopyroxene-olivine basalt lavas. The zircon F.T. ages of the Koji Tuff Member were reported as $21.2 \pm 1.0 \mathrm{Ma}$ by Yamasaki and Ganzawa (1989) and as $19.9 \pm 1.4,21.3 \pm 1.3,21.9 \pm 1.3$ Ma by Yoshitani et al. (1995). Geological age of the Kori Formation is thought to range from the early Middle Miocene to the early Late Miocene based on the Daijima type flora and the F.T. ages of the Koji Tuff Member and F.T. age (14.6 \pm 0.7 Ma; Yamasaki and Ganzawa, 1989) of the Kumi Formation.

The Kumi Formation is divided into five members of the Hei Tuff and Siltstone Alternation, Kumi Sandstone, Utagi Mudstone, Igo Mudstone, and Iinoyama Diatomite Members (Yamasaki, 1991). This formation conformably over- lies the Kori Formation. The Hei Tuff and Siltstone Alternation Member is composed of fine-coarse grained acidic tuff, pumice tuff, and siltstone alternation. The Kumi Sandstone Member is contemporaneous heterotopic facies with the Hei Tuff and Siltstone Alternation Member, and is composed of medium sandstone and mudstone alternation, pebble-granule conglomerate and acidic tuff. The lower part of the Iinoyama Diatomite Member is made of massive diatomite and interfingered with the Utagi Mudstone Member which is composed of black-gray mudstone and fine-coarse sandstone, whereas, the upper part of the Iinoyama Diatomite Member is also interfingered with the Igo Mudstone Member which is composed of massive sandy mudstone and fine-coarse sandstone (Yamasaki, 1992). Most of the Utagi Member is distributed in the southern part of the Oki-Dogo Island, and conformably overlies the Hei Tuff and Siltstone Alternation and the Kumi Sandstone Members. Geological age of the Kumi Formation is thought to be the early Late Miocene-the middle Late Miocene based on the foraminiferal assemblage (Okubo and Takayasu, 1980), the diatom assemblage (Yokota, 1984; Yamasaki et al., 1990; Yamasaki, 1992) and on F.T. ages 


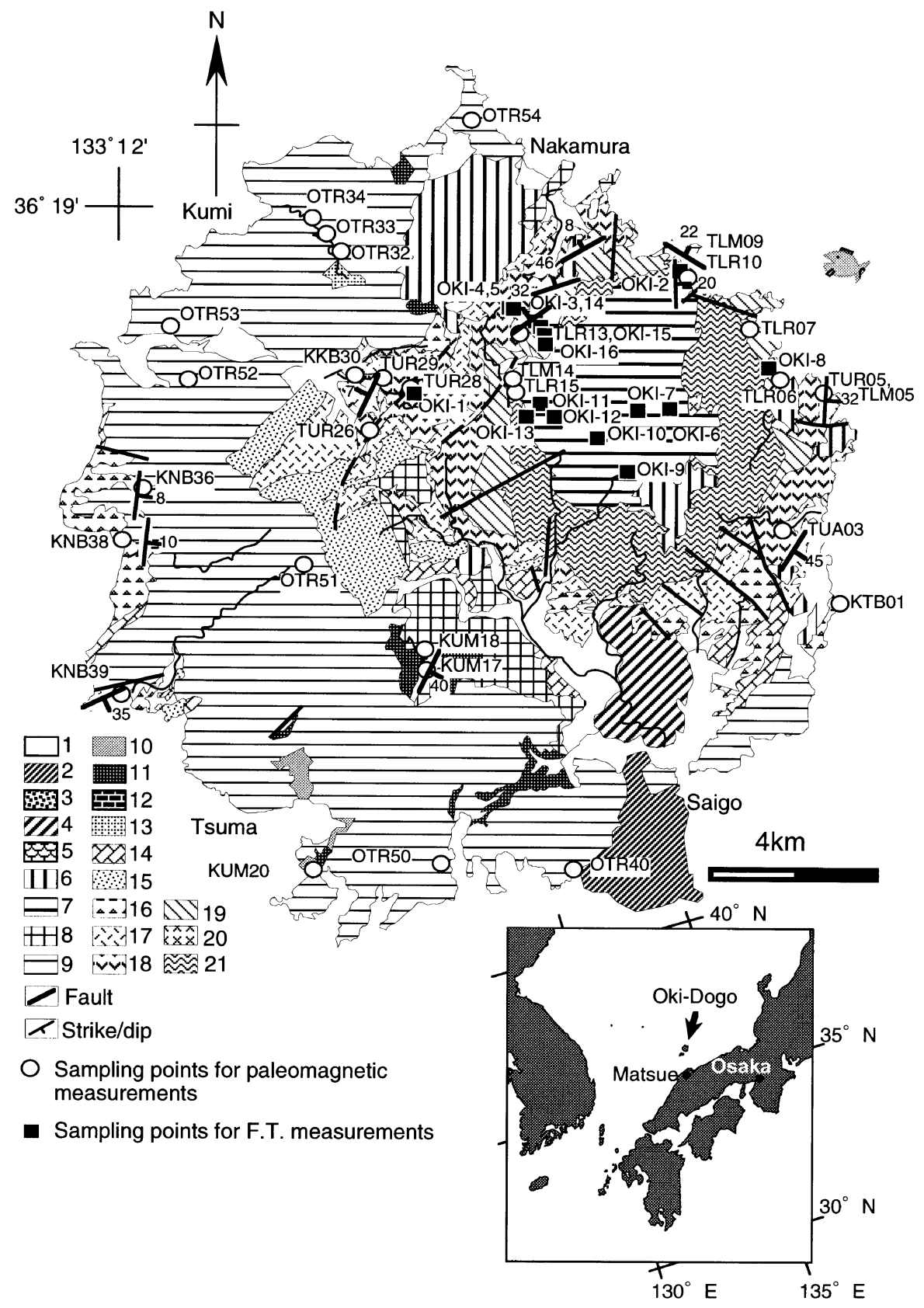

Fig. 2. Locality map of the Oki-Dogo Island and geological map. 1: Alluvium, 2: Misaki Basalt, 3: Nijiyama Gravel Beds, 4: Saigo Basalt, 5: Togo Gravel Beds, 6: Omine Basalt, 7: Tsuzurao Quartz Rhyolite, 8: Hei Trachyte, 9: Oki Trachyte-Rhyolite, 10: Tsuma Formation, 11 14: Kumi Formation (11: Igo Mudstone Member/Utagi Mudstone Member, 12: Iinoyama Diatomite Member, 13: Kumi Sandstone Member, 14: Hei Tuff-Siltstone Alternation Member), 15 17: Kori Formation (15: Ohzuku Conglomerate Member, 16: Togo Basalt, Kori Basalt, and Nagu Volcanics Members, 17: Koji Tuff Member), 18 19: Tokibariyama Formation (18: upper member, 19: lower member), 20: Younger granite, 21: Basement Rocks (Oki Metamorphics and Granite). After Kojima et al. (1995), Sawada et al. (1999), and Yamasaki (1992).

(14.6 \pm 0.7 Ma: Yamasaki and Ganzawa, 1989).

The Oki Trachyte-Rhyolite is widely distributed in the western part of the Oki-Dogo Island. It is composed of rhyolite and trachyte lavas and pyroclastic rocks, and unconformably overlies the Tokibari, Kori, Kumi, and Tsuma Formations. This formation was not tectonically deformed. Iwata et al. (1988) reported the $\mathrm{Rb}-\mathrm{Sr}$ whole-rock isochron age of $6.8 \pm 0.2 \mathrm{Ma}$.

\subsection{Geological structures}

The study area is characterized by a dome structure in the
Tokibariyama and Kori Formations. The basement rocks, which are covered by the Tsuzurao Quartz Rhyolite unconformably, crop out in the core of the dome. The north-western part of the dome dips gently to the northwest, whereas the eastern part dips steeply to the east. In the western half of the study area, a syncline with an axis trending N-S exists in the Kori and Kumi Formations, and the Oki TrachyteRhyolite is horizontally distributed covering this syncline unconformably. 


\section{Fission-Track Dating}

\subsection{Samples and measurements}

We collected samples from 15 sites for F.T. dating shown in Fig. 2 and Table 1, and obtained reliable data from 3 samples of OKI-7, 13, and 15. OKI-7 is from rhyolitic auto-brecciated lava of the Tsuzurao Quartz Rhyolite. OKI-13 and OKI-15 are the matrix of rhyolitic lapilli tuff and rhyolitic coarse tuff of the lower member of the Tokibariyama Formation.

All the samples were crushed to $75-250 \mu \mathrm{m}$ fraction. After panning, heavy liquid separation and magnetic separation, zircon grains were picked out by hand. Zircon grains were immersed in $45 \% \mathrm{HF}$ at $80^{\circ} \mathrm{C}$ for 2 hours to remove minute glasses, rock fragments and minerals clinging to the grains. After this treatment, 300 grains of zircon were taken from $3.3 \mathrm{~kg}$ of OKI-7, 300 grains from $5.0 \mathrm{~kg}$ of OKI-13 and 200 grains from $5.0 \mathrm{~kg}$ of OKI-15.

The age determination was done by the external detector method with zeta calibration (Hurford, 1990). The zircon grains were mounted in PFA Teflon sheets. Crystal external $(2 \pi)$ surfaces were used for OKI-13 and OKI-15, however crystal internal $(4 \pi)$ surfaces were used for OKI-7 because its crystal external $(2 \pi)$ surfaces had many scars. Etching was done using $\mathrm{KOH}-\mathrm{NaOH}$ melt at $225^{\circ} \mathrm{C}$. OKI-7, OKI-13, and OKI-15 were etched for 77, 76, and 49 hours, respectively. The zircon mounts and a standard glass (NIST, SRM-612) were covered by uranium-free muscovite detectors and were irradiated with thermal neutron in a pneumatic tube (cd-ratio: 3.5) of JRR-4 of Japan Atomic Energy Research Institute (Tokai village). After the irradiation, muscovite detectors were eched in $48 \% \mathrm{HF}$ for 30 minutes at room temperature. We used zeta values of 343.6 (for the $2 \pi$ surface), and 350.6 (for the $4 \pi$ surface) determined for dosimeter glass SRM612 using the Fish Canyon Tuff and Buluk Member Tuff (Hurford, 1990).

\subsection{Results of F.T. dating}

The results of the measurements are shown in Table 2. These passed $\chi^{2}$-test by over $5 \%$.

The age of OKI-13 and OKI-15 are 23.7 \pm 1.3 and $20.0 \pm$ $2.3 \mathrm{Ma}$, respectively. These ages are consistent with the K-Ar age $(19.7 \pm 0.6 \mathrm{Ma})$ of the potassium feldspar of the younger granite intruded into the Tokibariyama Formation (Tainosho et al., 1991). These results suggest that the Tokibariyama Formation was formed in the early Early Miocene.

The age of OKI-7 is 5.0 $\pm 0.2 \mathrm{Ma}$. The sample of OKI7 was considered to belong to the Tokibariyama Formation according to a previous study (Yamasaki, 1992), however we suggest the possibility that OKI-7 pertains to the Tsuzurao Quartz Rhyolite based on its age.

\section{Paleomagnetism}

\subsection{Samples and measurements}

We collected paleomagnetic samples from a total of 30 sites at 4 stratigraphic units (Oki Trachyte-Rhyolite, Kumi, Kori, and Tokibariyama Formations) consisting of the Miocene volcanic sedimentary strata in Oki-Dogo Island (Fig. 2, Table 1). More than five cores drilled by a standard size portable engine corer or three hand-picked samples were taken from each site. All the samples were oriented by a magnetic compass. In the laboratory, three or more cores were drilled from each hand-picked sample, and cut into two
Table 1. Fission-track and Paleomagnetic samples of Oki-Dogo Island.

\begin{tabular}{cccl} 
F.T. samples & & & \\
\hline site & $\begin{array}{c}\text { Latitude } \\
\mathrm{N}\end{array}$ & $\begin{array}{c}\text { Longitude } \\
\mathrm{E}\end{array}$ & Rock type \\
\hline OKI-1 & $36^{\circ} 16.5^{\prime}$ & $133^{\circ} 16.0^{\prime}$ & Rhyolite lava \\
OKI-2 & $36^{\circ} 18.5^{\prime}$ & $133^{\circ} 19.7^{\prime}$ & Rhyolite lava \\
OKI-3 & $36^{\circ} 17.5^{\prime}$ & $133^{\circ} 17.6^{\prime}$ & Rhyolite tuff \\
OKI-4 & $36^{\circ} 17.6^{\prime}$ & $133^{\circ} 17.4^{\prime}$ & Dacite lava \\
OKI-5 & $36^{\circ} 17.6^{\prime}$ & $133^{\circ} 17.5^{\prime}$ & Andesite lava \\
OKI-6 & $36^{\circ} 16.3^{\prime}$ & $133^{\circ} 20.2^{\prime}$ & Andesite lava \\
OKI-7 & $36^{\circ} 16.2^{\prime}$ & $133^{\circ} 19.9^{\prime}$ & Rhyolite lava \\
OKI-8 & $36^{\circ} 16.6^{\prime}$ & $133^{\circ} 21.8^{\prime}$ & Rhyolite tuff \\
OKI-9 & $36^{\circ} 15.3^{\prime}$ & $133^{\circ} 19.7^{\prime}$ & Rhyolite tuff \\
OKI-10 & $36^{\circ} 16.0^{\prime}$ & $133^{\circ} 19.2^{\prime}$ & Rhyolite tuff \\
OKI-11 & $36^{\circ} 16.2^{\prime}$ & $133^{\circ} 18.3^{\prime}$ & Rhyolite tuff \\
OKI-12 & $36^{\circ} 16.2^{\prime}$ & $133^{\circ} 18.0^{\prime}$ & Rhyolite tuff \\
OKI-13 & $36^{\circ} 16.0^{\prime}$ & $133^{\circ} 17.6^{\prime}$ & Rhyolite tuff \\
OKI-14 & $36^{\circ} 17.5^{\prime}$ & $133^{\circ} 17.6^{\prime}$ & Rhyolite tuff \\
OKI-15 & $36^{\circ} 17.4^{\prime}$ & $133^{\circ} 17.8^{\prime}$ & Rhyolite tuff \\
OKI-16 & $36^{\circ} 17.3^{\prime}$ & $133^{\circ} 17.8^{\prime}$ & Rhyolite tuff \\
\hline
\end{tabular}

Paleomagnetic samples

$N$ : number of rock samples

\begin{tabular}{|c|c|c|c|c|}
\hline site & $N$ & $\begin{array}{c}\text { Latitude } \\
\text { N }\end{array}$ & $\begin{array}{c}\text { Longitude } \\
\text { E }\end{array}$ & Rock type \\
\hline \multicolumn{5}{|c|}{ Oki Trachyte-Rhyolite } \\
\hline OTR32 & 4 & $36^{\circ} 18.3^{\prime}$ & $133^{\circ} 15.0^{\prime}$ & Rhyolite lava \\
\hline OTR33 & 4 & $36^{\circ} 18.5^{\prime}$ & $133^{\circ} 14.8^{\prime}$ & Rhyolite lava \\
\hline OTR34 & 3 & $36^{\circ} 18.7^{\prime}$ & $133^{\circ} 14.7^{\prime}$ & Rhyolite lava \\
\hline OTR40 & 5 & $36^{\circ} 10.8^{\prime}$ & $133^{\circ} 18.8^{\prime}$ & Rhyolite lava \\
\hline OTR50 & 7 & $36^{\circ} 10.5^{\prime}$ & $133^{\circ} 16.7^{\prime}$ & Rhyolite lava \\
\hline OTR51 & 3 & $36^{\circ} 14.3^{\prime}$ & $133^{\circ} 14.7^{\prime}$ & Rhyolite lava \\
\hline OTR52 & 4 & $36^{\circ} 14.7^{\prime}$ & $133^{\circ} 12.8^{\prime}$ & Rhyolite lava \\
\hline OTR53 & 7 & $36^{\circ} 17.3^{\prime}$ & $133^{\circ} 12.5^{\prime}$ & Rhyolite lava \\
\hline OTR54 & 6 & $36^{\circ} 20.2^{\prime}$ & $133^{\circ} 17.2^{\prime}$ & Rhyolite lava \\
\hline \multicolumn{5}{|c|}{ Kumi Formation } \\
\hline KUM17 & 3 & $36^{\circ} 12.8^{\prime}$ & $133^{\circ} 16.1^{\prime}$ & Mudstone \\
\hline KUM18 & 5 & $36^{\circ} 13.2^{\prime}$ & $133^{\circ} 16.0^{\prime}$ & Mudstone \\
\hline KUM20 & 7 & $36^{\circ} 10.3^{\prime}$ & $133^{\circ} 14.8^{\prime}$ & Mudstone \\
\hline \multicolumn{5}{|c|}{ Kori Formation } \\
\hline KTB1 & 3 & $36^{\circ} 13.7^{\prime}$ & $133^{\circ} 22.8^{\prime}$ & Basalt lava \\
\hline KKB30 & 9 & $36^{\circ} 16.8^{\prime}$ & $133^{\circ} 15.3^{\prime}$ & Basalt lava \\
\hline KNB36 & 5 & $36^{\circ} 15.3^{\prime}$ & $133^{\circ} 12.0^{\prime}$ & Basalt lava \\
\hline KNB38 & 7 & $36^{\circ} 15.8^{\prime}$ & $133^{\circ} 11.5^{\prime}$ & Basalt lava \\
\hline KNB39 & 5 & $36^{\circ} 12.8^{\prime}$ & $133^{\circ} 11.8^{\prime}$ & Basalt lava \\
\hline \multicolumn{5}{|c|}{ Tokibariyama Formation } \\
\hline TUA03 & 8 & $36^{\circ} 14.7^{\prime}$ & $133^{\circ} 22.0^{\prime}$ & Andesite lava \\
\hline TUR05 & 3 & $36^{\circ} 16.3^{\prime}$ & $133^{\circ} 22.5^{\prime}$ & Rhyolitic tuff \\
\hline TLM05 & 7 & $36^{\circ} 16.3^{\prime}$ & $133^{\circ} 22.5^{\prime}$ & Mudstone \\
\hline TUA26 & 7 & $36^{\circ} 16.2^{\prime}$ & $133^{\circ} 15.4^{\prime}$ & Andesite lava \\
\hline TUA28 & 11 & $36^{\circ} 16.5^{\prime}$ & $133^{\circ} 16.0^{\prime}$ & Andesite lava \\
\hline TUA29 & 5 & $36^{\circ} 16.7^{\prime}$ & $133^{\circ} 15.5^{\prime}$ & Andesite lava \\
\hline TLR06 & 3 & $36^{\circ} 16.4^{\prime}$ & $133^{\circ} 21.9^{\prime}$ & Rhyolitic tuff \\
\hline TLR07 & 7 & $36^{\circ} 17.2^{\prime}$ & $133^{\circ} 21.5^{\prime}$ & Rhyolitic tuff \\
\hline TLM09 & 6 & $36^{\circ} 18.0^{\prime}$ & $133^{\circ} 20.6^{\prime}$ & Mudstone \\
\hline TLR10 & 14 & $36^{\circ} 17.8^{\prime}$ & $133^{\circ} 20.5^{\prime}$ & Rhyolitic tuff \\
\hline TLR13 & 12 & $36^{\circ} 17.4^{\prime}$ & $133^{\circ} 17.8^{\prime}$ & Rhyolitic tuff \\
\hline TLM14 & 6 & $36^{\circ} 16.9^{\prime}$ & $133^{\circ} 17.3^{\prime}$ & Rhyolitic tuff \\
\hline TLR15 & 6 & $36^{\circ} 16.8^{\prime}$ & $133^{\circ} 17.3^{\prime}$ & Rhyolitic tuff \\
\hline
\end{tabular}


Table 2. Fission-track data of zircons from the Tokibariyama Formation and the Tsuzurao Quartz Rhyolite, the Oki-Dogo Island. $\rho(N)$ : fission-track density (total number of tracks counted), subscripts $s$ and $i$ for spontaneous and induced tracks in zircons, respectively, and $d$ for induced tracks from the dosimetory glass. OKI-13 and 15 were measured on $2 \pi$ surface, and OKI- 7 was measured on $4 \pi$ surface using 0.5 for the $4 \pi / 2 \pi$ geometry correction factor. $P\left(\chi^{2}\right)$ is probability of obtaining $\chi^{2}$ value for $v$ degrees of freedom (where $v=$ No. crystals-1); $P\left(\chi^{2}\right)>5 \%$ is shown. Thermal neutron irradiation was done at pneumatic tube of JRR-4 of Japan Atomic Energy Research Institute (Tokai village). The errors are shown by 1 sigma.

\begin{tabular}{cccccccccc}
\hline $\begin{array}{c}\text { Sample } \\
\text { code }\end{array}$ & $\begin{array}{c}\text { No. of } \\
\text { crystals }\end{array}$ & $\begin{array}{c}\text { Spontaneous } \\
\rho_{s}(\Sigma N s) \\
\left(10^{5-2}\right)\end{array}$ & $\begin{array}{c}\text { Induced } \\
\rho_{i}(\Sigma N i) \\
\left(10^{5-2}\right)\end{array}$ & $\begin{array}{c}\text { Dosimeter } \\
\rho_{d}(\Sigma N \phi) \\
\left(10^{5-3}\right)\end{array}$ & $\begin{array}{c}P\left(\chi^{2}\right) \\
(\%)\end{array}$ & $\begin{array}{c}\text { U-content } \\
(\mathrm{ppm})\end{array}$ & $\begin{array}{c}\text { Age } \\
( \pm 1 \sigma) \\
(\mathrm{Ma})\end{array}$ & $\begin{array}{c}\text { Latitude } \\
\mathrm{N}\end{array}$ & $\begin{array}{c}\text { Longitude } \\
\mathrm{E}\end{array}$ \\
\hline OKI-7 & 24 & $1.413(526)$ & $4.700(2100)$ & $1.098(3917)$ & 73.5 & 640.3 & $5.0 \pm 0.2$ & $36^{\circ} 16.2^{\prime}$ & $133^{\circ} 19.9^{\prime}$ \\
OKI-13 & 38 & $1.133(739)$ & $1.337(872)$ & $0.802(2650)$ & 9.4 & 602.6 & $23.7 \pm 1.3$ & $36^{\circ} 16.0^{\prime}$ & $133^{\circ} 17.6^{\prime}$ \\
OKI-15 & 13 & $0.695(180)$ & $1.378(357)$ & $1.095(3907)$ & 12.3 & 461.8 & $20.0 \pm 2.3$ & $36^{\circ} 17.4^{\prime}$ & $133^{\circ} 17.8^{\prime}$ \\
\hline
\end{tabular}

Table 3. Summary of paleomagnetic results of the Oki-Dogo Island.

$N$ : number of rock samples, $D$ : declination, $I$ : inclination,

$k$ : Fisherian precision parameter, $\alpha_{95}: 95 \%$ confidence limit

\begin{tabular}{cccccr}
\hline site & $N$ & $\begin{array}{c}D \\
\text { deg. }\end{array}$ & $\begin{array}{c}\text { I } \\
\text { deg. }\end{array}$ & $k$ & $\begin{array}{r}\alpha_{95} \\
\text { deg. }\end{array}$ \\
\hline \multicolumn{7}{l}{ Oki Trachyte-Rhyolite } \\
OTR32 & 4 & 127.6 & -25.9 & 52.1 & 12.9 \\
OTR34 & 3 & 202.0 & -55.1 & 94.0 & 12.8 \\
OTR40 & 5 & 164.6 & -46.0 & 106.2 & 7.5 \\
OTR50 & 7 & 184.5 & -47.3 & 30.9 & 11.0 \\
OTR51 & 3 & 152.3 & -39.6 & 80.0 & 13.9 \\
OTR52 & 4 & 186.0 & -19.1 & 42.6 & 14.2 \\
OTR53 & 7 & 116.5 & -79.9 & 40.2 & 9.6 \\
OTR54 & 6 & 164.3 & -54.1 & 33.8 & 11.7 \\
\hline
\end{tabular}

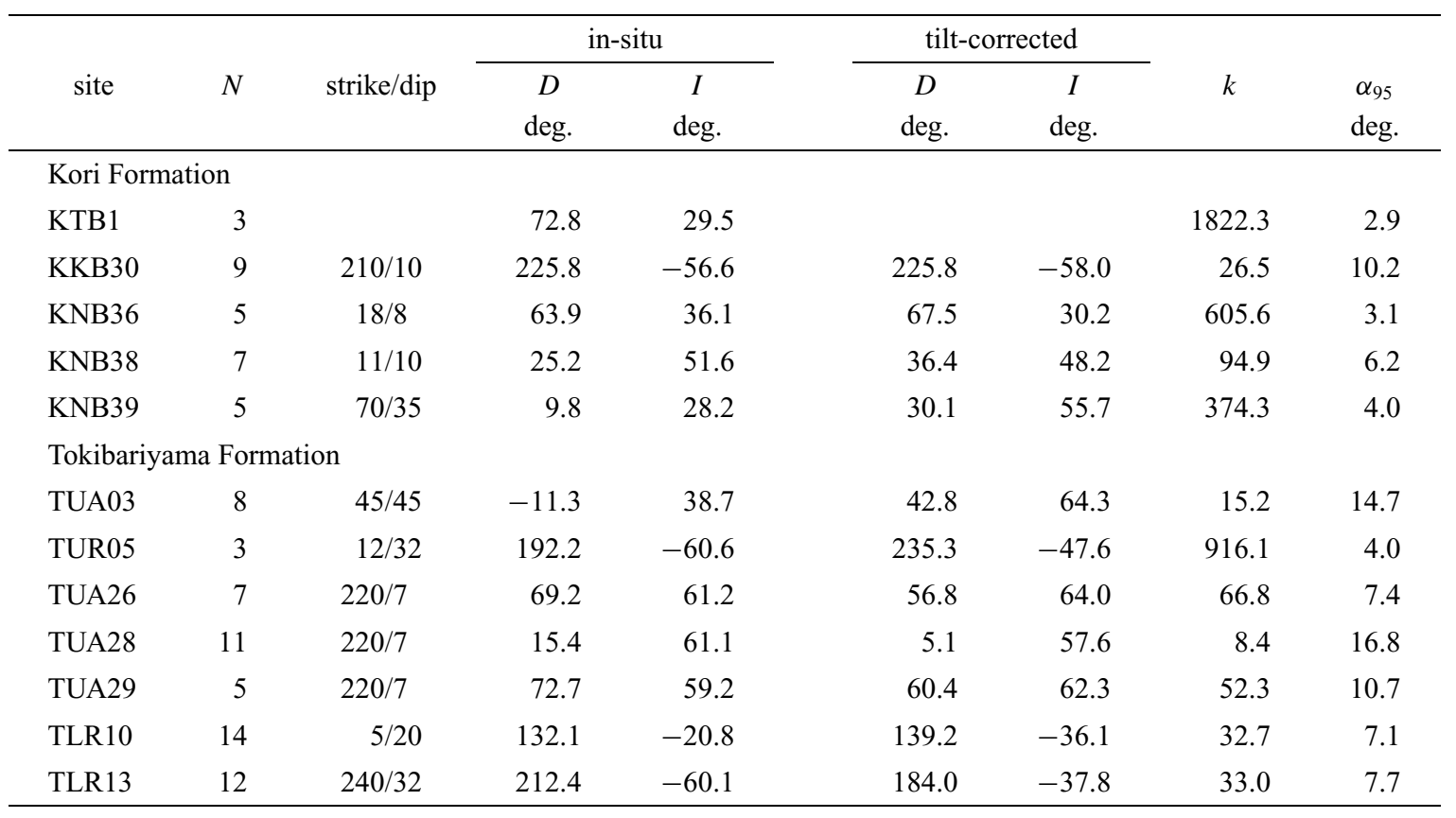

or more specimens.

Magnetic measurements were performed at Ibaraki University using a cryogenic magnetometer (2G model $750 \mathrm{R})$, alternating field (AF) and thermal demagnetizers (Natsuhara
Giken models DEM-8061 and TDE-91E), a low-field susceptibility meter (Bartington MS2) and a pulse magnetizer (Magnetic Measurement MMP9). Magnetic field intensity was less than $5 \mathrm{nT}$ in the thermal demagnetizer sample region. 
(a)
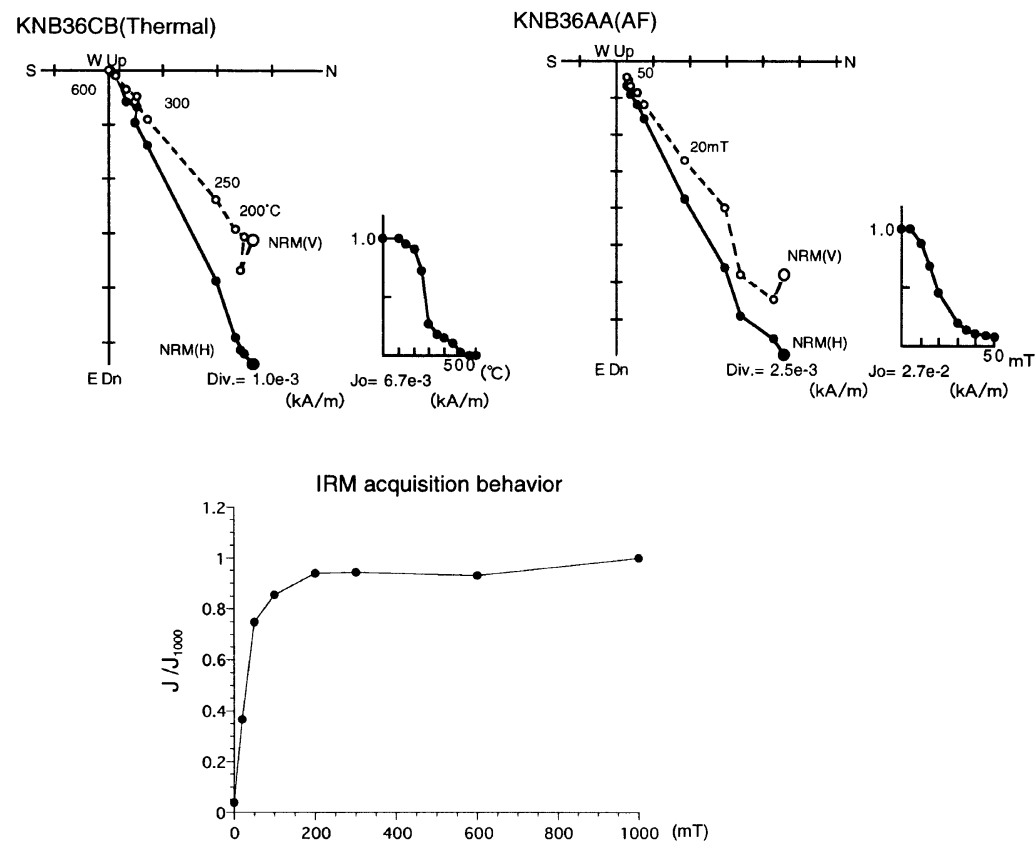

(b)
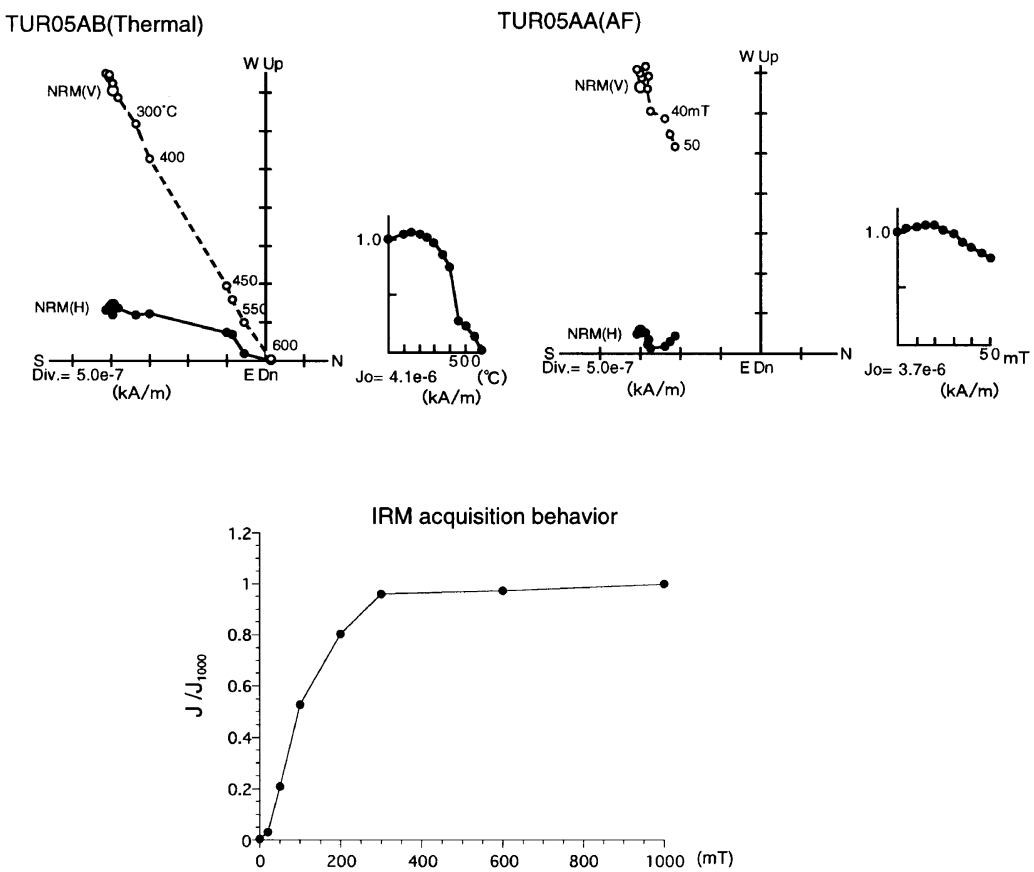

Fig. 3. Orthogonal projections of typical demagnetization behaviors, typical IRM acquisition curves and magnetic susceptibility fluctuations through the thermal runs. In the orthogonal projections, open circle denotes a projection on the N-S vertical plane and closed circle on the horizontal plane. (a) The AF result exhibits similar demagnetization paths with the thermal one at portions higher than $10 \mathrm{mT}$. (b) and (c) The AF result exhibit different demagnetization paths with the thermal one. IRM acquisition carried out at 20,50, 100, 200, 300, 600, and $1000 \mathrm{mT}$, respectively. (d) An example for specimens being not able to yeild ChRMs. (e) Magnetic susceptibility fluctuations through the thermal runs of specimens shown above.

To determine an appropriate demagnetization procedure at each site, we selected two pilot specimens from each site and demagnetized progressively, one thermally and another by AF. The AF demagnetization was statistically done at three orthogonal axes up to $50 \mathrm{mT}$ at $5 \mathrm{mT}$ intervals, and the thermal one from $100^{\circ} \mathrm{C}$ to $600^{\circ} \mathrm{C}$ at $50^{\circ} \mathrm{C}$ intervals. Magnetic susceptibility was measured at each thermal demagnetization step to monitor possible chemical changes caused by heating. Acquisition of isothermal remanent magnetization (IRM) was progressively performed every $25 \sim 50 \mathrm{mT}$ up to $1000 \mathrm{mT}$ to know a specimen's coercivity spectrum.

\subsection{Rock magnetic and paleomagnetic results}

Stepwise demagnetizations for the pilot specimens yielded characteristic remanent magnetization (ChRM) components at 20 sites (Table 3 and Figs. 3(a), (b), (c) for examples), showing an identical demagnetization pattern in both proce- 
(c)

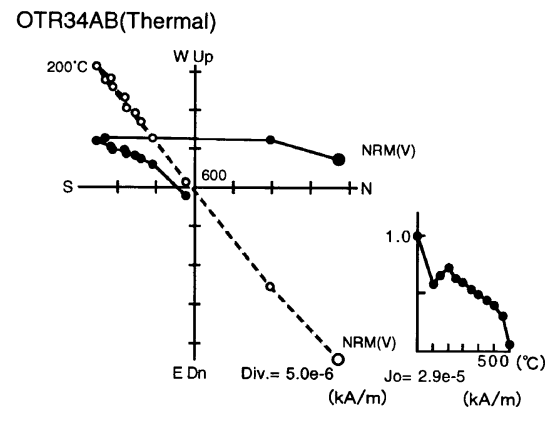

OTR34AA(AF)

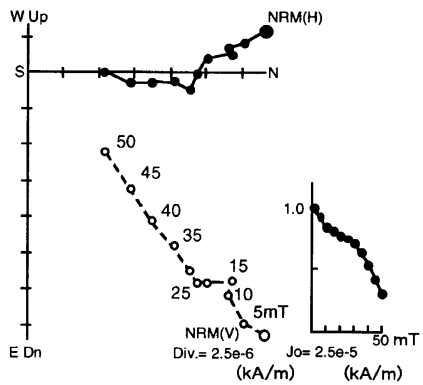

(d)
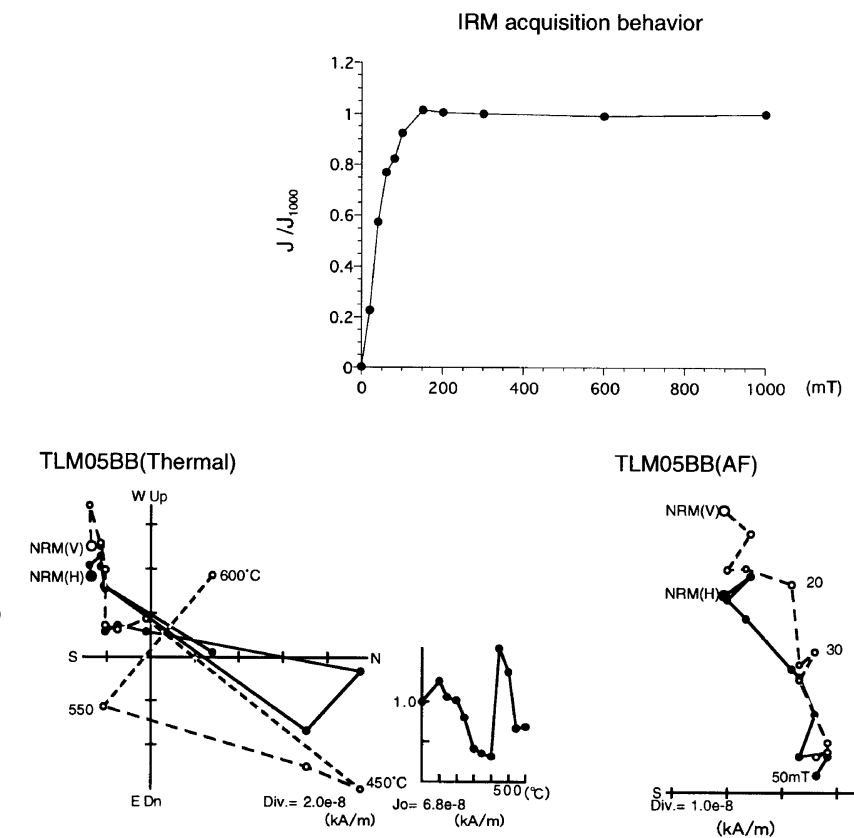

TLM05BB(AF)

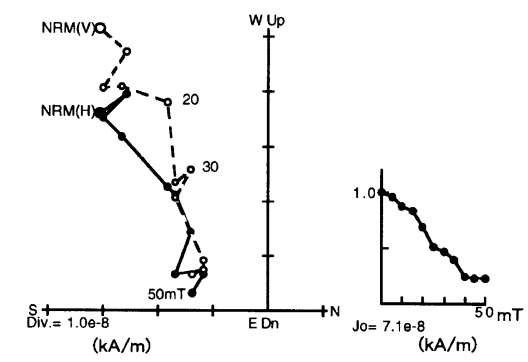

(e)

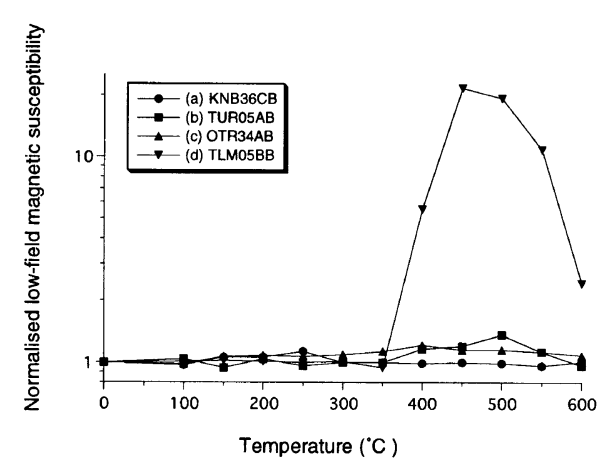

Fig. 3. (continued).

dures at each site. A ChRM was determined by the principal component analysis (Kirschvink, 1980) applied to data composing a liner segment toward the origin on a demagnetization diagram. At other sites, thermal demagnetization exhibits scattered directions above $400^{\circ} \mathrm{C}$ at which magnetic susceptibility largely goes up, and AF shows that the remanence has not moved to the origin (Figs. 3(d), (e) for examples).

The IRM acquisition was carried out on specimens from the 20 sites where ChRM were extracted. The results exhibit dominant low coercivity of less than 200 300 mT and negligible higher coercivity spectra at the 20 sites (Fig. 3), indicating low coercivity magnetic minerals like magnetites, maghemites, and magnetic iron sulfides as possible magnetic carriers.

Thermal demagnetization results from the sites producing ChRMs except TUR05 and OTR34 show that the remanence vectors sharply decline from $200^{\circ}$ to $300^{\circ} \mathrm{C}$, slowly move toward the origin from $300^{\circ}$ to $550^{\circ} \mathrm{C}$ and disappear by $600^{\circ} \mathrm{C}$ (Fig. 3(a)). This result also shows that the magnetization above $200^{\circ} \mathrm{C}$ consists of a single component appearing to be a ChRM. The component can be separated into two temperature ranges at around $300^{\circ} \mathrm{C}: \mathrm{i}$ ) a dominant lower temperature component, and ii) a minor higher temperature component. 
Tokibariyama Formation

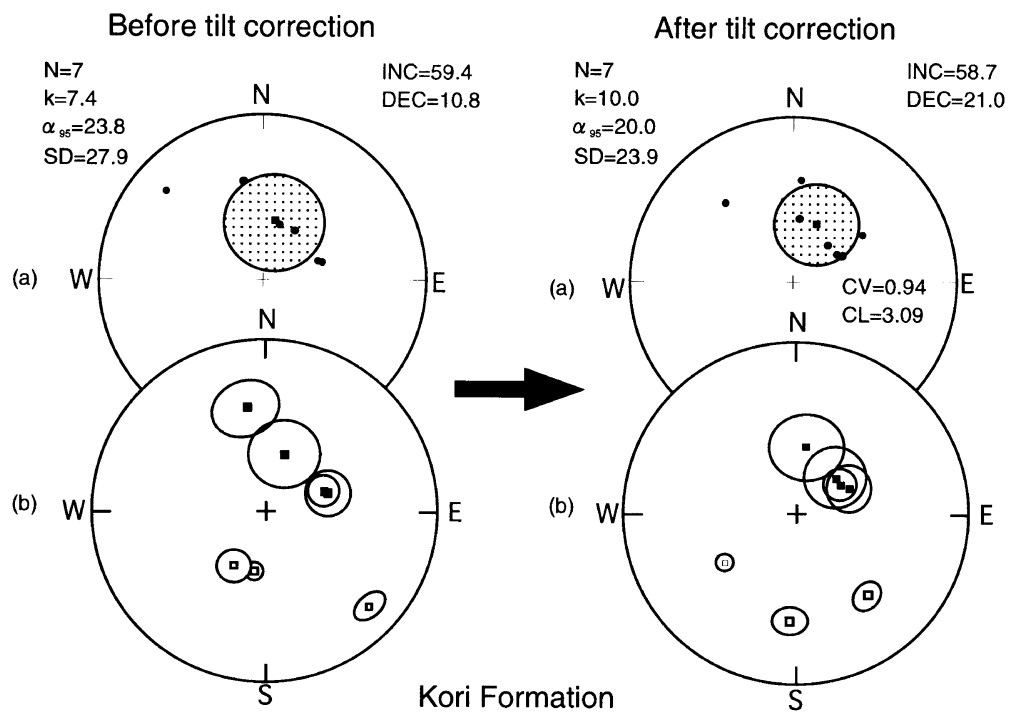

Before tilt correction

After tilt correction

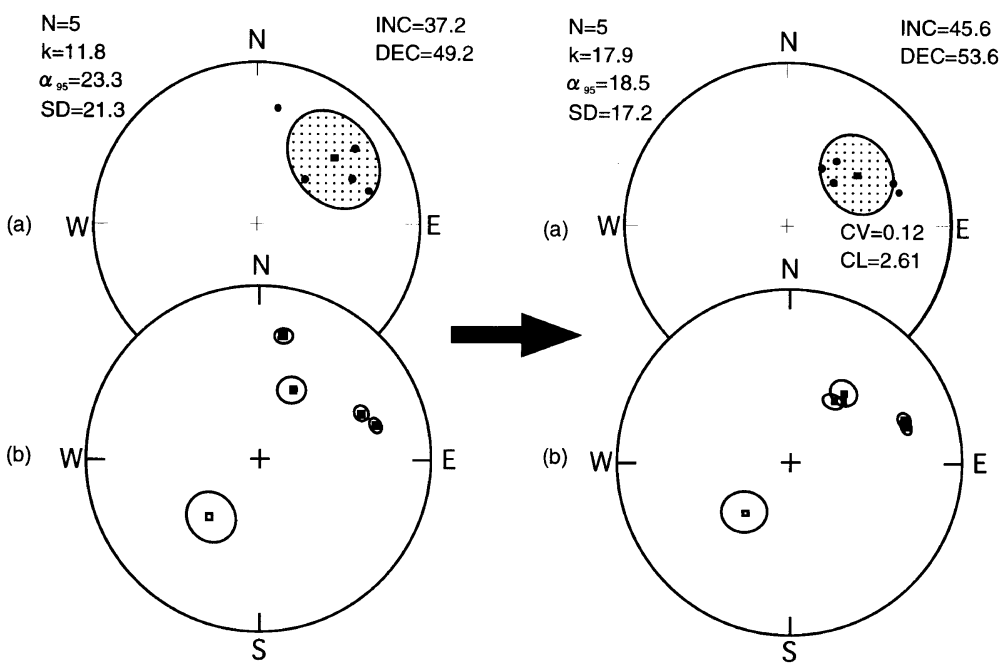

Fig. 4. Comparison of ChRM with before and after tilt correction. (a) Average paleomagnetic directions of the Tokibariyama and Kori Formations with 95\% confidence circles. A circle denotes site-mean direction, which is showed by converting reversed directions to normal. Squares and shaded ovals indicate overall means and their $95 \%$ confidence limit. $N$ : number of sites, $k$ : Fisherian precision parameter, $\alpha_{95}: 95 \%$ confidence limit, SD: standard deviation, Inc: inclination, Dec: declination, CV: correlation value, CL: 95\% confidence limit of the correlation valve. CV and CL are used in the correlation test (McFadden, 1990) (b) Equal-area projections of site-mean directions with 95\% confidence circles. Solid squares refer to lower hemisphere, and the open squares refer to upper hemisphere.

Since the susceptibility does not change much through the thermal demagnetization runs (Fig. 3(e)), the lower temperature component seems not to be carried by iron sulfides, but by low coercivity magnetites and/or maghemites. The AF results exhibit similar demagnetization paths with the thermal paths at portions higher than $10 \mathrm{mT}$, suggesting that the ChRMs can be extracted effectively by AF demagnetization. At these sites, therefore, we demagnetized other specimens by AF and extracted components higher than 10 $\mathrm{mT}$ as ChRMs.

The result of TUR05 thermal demagnetization shows that the remanent vector declines abruptly between 400 and $450^{\circ} \mathrm{C}$, moves straight to the origin and disappears by $600^{\circ} \mathrm{C}$. The IRM acquisition curve from this site exhibits saturation at $300 \mathrm{mT}$. These results indicate that the component higher than the $450^{\circ} \mathrm{C}$ might be carried by fine grain magnetites having a hard coercivity of close to $300 \mathrm{mT}$. Since this component is quite stable and is not removed effectively by AF (Fig. 3(b)), we demagnetized other specimens thermally and extracted components of higher than $450^{\circ} \mathrm{C}$ as ChRMs.

The result of OTR34 thermal demagnetization shows that the remanent vector turns from normal to reversed at $200^{\circ} \mathrm{C}$, and it declines toward the origin and disappears by $600^{\circ} \mathrm{C}$ (Fig. 3(c)). Magnetization higher than the $200^{\circ} \mathrm{C}$ portion consists of a single component seeming to be a ChRM, and the IRM acquisition curve of this sample shows its saturation by $100 \mathrm{mT}$ indicating that low coercivity minerals dominate the magnetic carriers. These results suggests magnetites as a 
magnetic carrier for the ChRM. However, the lower temperature portion which might be a recent overprint is not removed by AF. Thus, we demagnetized other specimens thermally and extracted components higher then $200^{\circ} \mathrm{C}$ as ChRMs.

According to sedimentary structures found near the sampling sites, we performed tilting correction of in-situ paleomagnetic results from all the sites except OTR series (Oki Trachyte-Rhyolite) and KTB1 (Kori Formation) which are thought not to have moved tectonically (Fig. 4). The result of the correction, shown separately for the Tokibariyama and Kori Formations (except KTB1), indicates that the confidential circles are reduced after the correction in both cases (Fig. 4) suggesting that the correction is efficient to provide a better estimation of the remanent directions. To assess whether the correction is significant, we apply the correlation test proposed by Mcfadden (1990). The test takes correlation between the corrected direction and the bedding orientation at each site, sums up all the sites, and compares the sumed correlation value to the confidence limit provided at every number of samples. As the result, the correlation values from both the formations are smaller than the limits (Fig. 4) suggesting the correction is significantly effective.

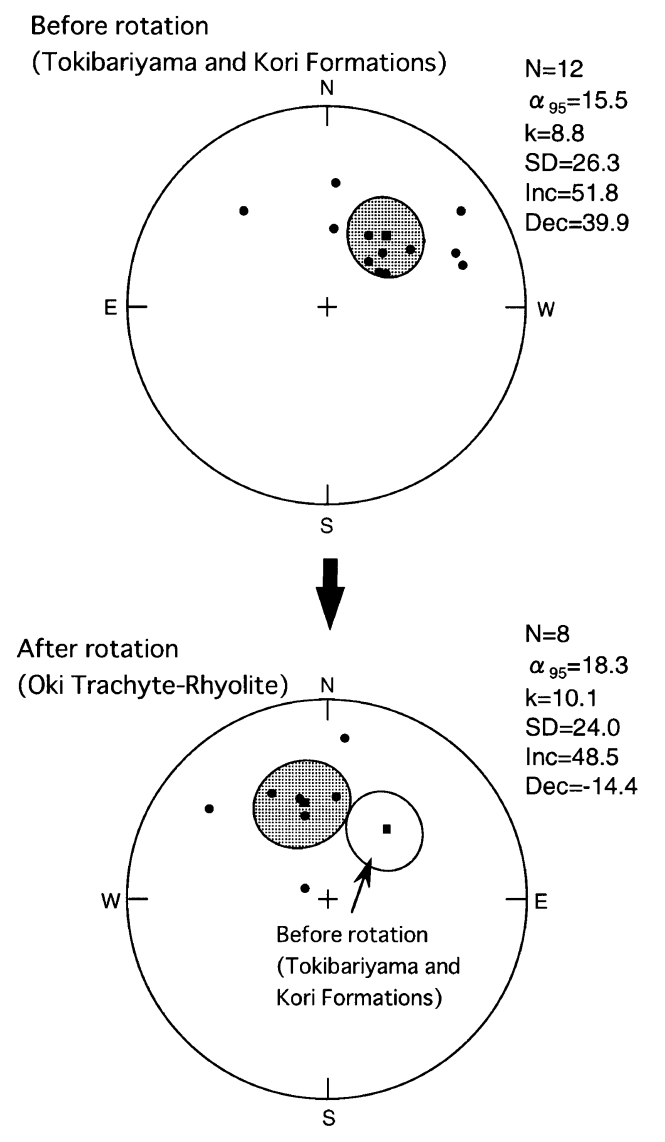

Fig. 5. Average paleomagnetic directions of before and after of rotation with $95 \%$ confidence circles. Circle denotes site-mean direction, which is showed by converting reversed directions to normal. That of the Tokibariyama and Kori Formations is before rotation and that of the Oki Trachyte-Rhyolite is after rotation. Squares and shaded ovals indicate overall means and their $95 \%$ confidence limit. $N$ : number of sites, $k$ : Fisherian precision parameter, $\alpha_{95}: 95 \%$ confidence limit, SD: standard deviation, Inc: inclination, Dec: declination.
Therefore, we use the corrected directions for further discussion.

Since distributions of site mean directions from the Tokibariyama and Kori Formations are similar, we treated these data together as there is no significant tectonic movement between these formations. On the other hand, the distribution of site mean directions from the Oki Trachyte-Rhyolite looks discrepant with those of other formations. The average direction from the Tokibariyama and Kori Formations points significantly in an eastward declination $\left(40 \pm 15^{\circ}\right)$ but the one from the Oki Trachyte-Rhyolite does not show a significant difference from the present axial dipole field direction (Fig. 5). This result suggests that a clockwise rotation of $\sim 40^{\circ}$ occurred between the age of deposition of the Tokibariyama and Kori Formations and that of the Oki Trachyte-Rhyolite (Fig. 5).

\section{Discussion}

\subsection{Timing of clockwise rotation}

The geological age of the Tokibariyama and Kori Formations was determined as the Early Miocene (24-17 Ma) based on the F.T. ages and the Daijima type flora. The Rb-Sr age of the Oki Trachyte-Rhyolite was reported as $6.8 \mathrm{Ma}$ by Iwata et al. (1988). The timing of clockwise rotation is between 17 and $6.8 \mathrm{Ma}$. This result is consistent with that of Otofuji et al. (1991).

\subsection{Amount of clockwise rotation}

The mean paleomagnetic direction of the Tokibariyama and Kori Formations is $D=39.9^{\circ}, I=51.8^{\circ}, \alpha_{95}=15.5^{\circ}$, and that of the Oki Trachyte-Rhyolite is $D=-14.4^{\circ}, I=$ $48.5^{\circ}, \alpha_{95}=18.3^{\circ}$. The inclination of the Tokibariyama and Kori Formations is not different from that of the Oki Trachyte-Rhyolite, however the declination is different between them. Since the $\alpha_{95}$ area of the Oki Trachyte-Rhyolite contains the geocentric axial dipole field direction of this region, it can be said that the Oki Trachyte-Rhyolite has not been moved tectonically since the deposition. These results indicate that a clockwise rotation of $40^{\circ} \pm 15^{\circ}$ occured during the period after the deposition of the Tokibariyama and Kori Formations and before the time of the formation of the Oki Trachyte-Rhyolite.

\subsection{Geological evidence for the Japan Sea opening}

Transgression started slowly from the early Early Miocene because the Tokibariyama Formation contains lacustrine mudstone beds (Kojima et al., 1995) and the Kori Formation consists of basaltic submarine auto-brecciated lavas and conglomerate. Yamasaki (1992) reported that the Kori Formation and the lower Kumi Formation was deposited in fluvial to shallow sea environments. The timing of the clockwise rotation of the Oki-Dogo Island is consistent with that of the environment change from fluvial-shallow sea to deep sea.

According to the topography and geological structure of the sea floor between Oki-Dogo and the Shimane Peninsula, it is continuous and shows no differential movement. The topography which is shown in Fig. 6 is characterized by smooth continental shelf shallower than $100 \mathrm{~m}$ and no large faults were reported (Iwabuchi, 1968). Otofuji et al. (1991) reported paleomagnetic data indicating a clockwise rotation of the Kawai Formation, which is correlated with the Kumi Formation in Oki-Dogo based on the geological 


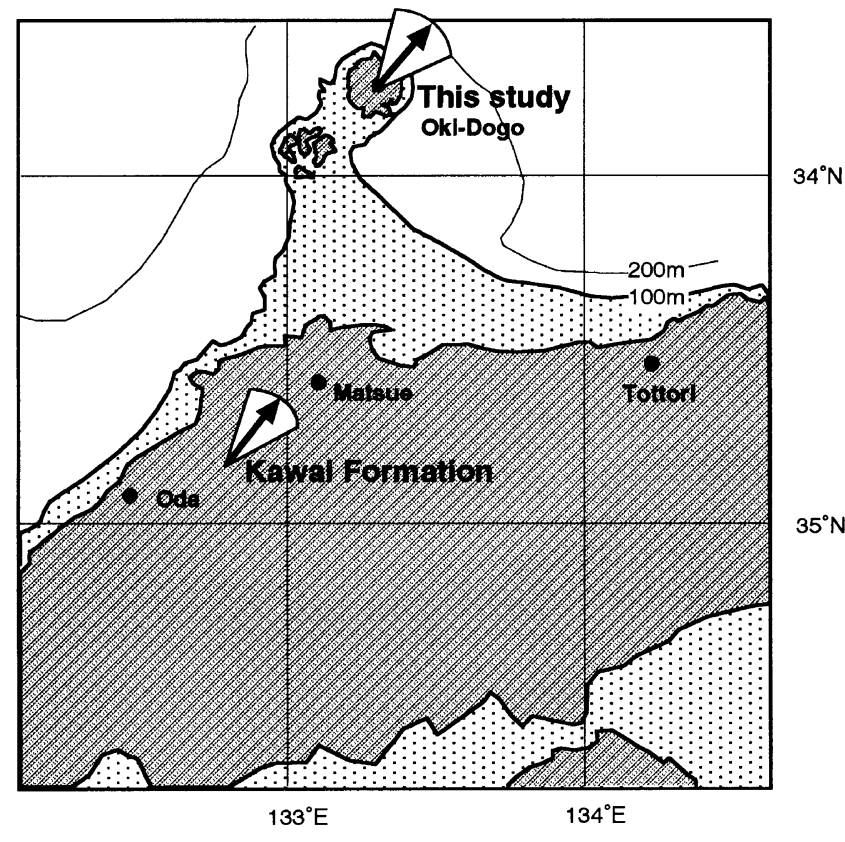

Fig. 6. Bathimetric map and Paleomagnetic declinations in the Chugoku district. The map was made being modified after Igi and Hattori (1991). The mean declinations indicated by the arrows are shown together with their $95 \%$ confidence limits $\left(=\sin ^{-1}\left[\sin \alpha_{95} / \cos I\right]\right.$, where $\alpha_{95}$ is the radius of the $95 \%$ confidence limit and $I$ is the inclination). The declination in the main land of southwest Japan is after Otofuji et al. (1991).

age, in the eastern part of Shimane Prefecture. The Kawai Formation consists mainly of sandstone. However, it is comformably covered by or party interfingered with the Kuri Formation composed of black shale and rhyolite-dacite pyroclastic rocks. These facies resemble that of the Kumi Formation (Yamauchi and Yoshitani, 1981). These results show that Oki-Dogo probably rotated together with Southwest Japan.

\section{Conclusions}

1. Paleomagnetic and F.T. age measurements show a clockwise rotation of $40^{\circ} \pm 15^{\circ}$ of the Oki-Dogo Island between 17 and 6.8 Ma.This result is consistent with the results of previous studies (e.g. Otofuji et al., 1991).

2. The timing of the clockwise rotation of Oki-Dogo Island related to the Japan Sea opening almost coincided with the timing of the environmental change from fluvial-shallow sea to deep sea.

Acknowledgments. The authors wish to thank Dr. M. Torii and Dr. T. Matsuda for their useful reviews and valuable comments. We thank Dr. A. J. Martin of Ibaraki University for a helpful review of the original manuscript, and Mr. J. Hashimoto of JCE for assistance in sampling.

\section{References}

Hurford, A. J., Standardization of fission track dating calibration: Recommendation by Fission Track Working Group of the I.U.G.S. Subcommision on Geochronology, Chem. Geol., 80, 171-178, 1990.

Igi, S. and H. Hattori, Geologic Atlas of Japan; Chugoku and Shikoku regions, Under the Supervision of the Geological Survey of Japan, ASAKURA Publishing Company, LTD., Tokyo, 1991 (in Japanese).

Ito, H., Polarity transitions of the geomagnetic field deduced from the natural remanent magnetization of Tertiary and Quaternary rocks in Southwest
Japan, J. Geomag. Geoelectr., 22(3), 273-290, 1970.

Iwabuchi, Y., Submarine Geology of the Southeastern part of the Japan Sea, Contributions from the Ins. Geo. Paleontology. Tohoku Univ., 66, 1-76, 1968 (in Japanese).

Iwata, M., H. Kagami, E. Takahashi, and H. Kurasawa, The Rb-Sr whole rock isochron age and genesis of Oki Trachyte-Rhyolite Group in Oki Dogo Island, Bull. Vol. Soc. Japan, 33, 79-86, 1988 (in Japanese with English abstract).

Jolivet, L., H. Shibuya, and M. Fournier, Paleomagnetic rotations and the Japan Sea opening, in Active Margins and Marginal Basins of the Western Pacific, pp. 355-369, Am. Geophys. Union, Washington, D.C., 1995.

Kano, K. and S. Nakano, Stratigraphic correlation of the Neogene in the San-in district, Southwest Japan, in the light of radiometric dating, Bull. Geol. Surv. Japan, 36, 427-438, 1985 (in Japanese with English abstract).

Kaneoka, I., E. Takahashi, and S. Zashu, K-Ar ages of alkali basalts from the Oki-Dogo Island, J. Geol. Soc. Japan, 83, 187-189, 1977.

Kawai, N., H. Ito, and S. Kume, Deformation of the Japanese Islands as inferred from rock magnetism, Geophys. J. Roy. astr. Soc., 6, 124-129, 1961.

Kirschvink, J. L., The least-squares line and plane and the analysis of paleomagnetic data, Geophys. J. Roy. astr. Soc., 62, 699-719, 1980.

Kojima, T., H. Komuro, and H. Murakami, The Tokibariyama Formation in the northeastern part of the Oki-Dogo Island, Geol. Rept. Shimane Univ., 14, 89-100, 1995 (in Japanese with English abstract).

McFadden, P. L., A new fold test for paleomagnetic studies, Geophys. J. Int., 103, 163-169, 1990.

Okubo, M. and K. Takayasu, First discovery of Miogypsina in OKI Island, west Japan, J. Geol. Soc. Japan, 86, 37-39, 1980 (in Japanese).

Otofuji, Y., T. Matsuda, and S. Nohda, Opening mode of the Japan Sea inferred from the paleomagnetism of the Japan arc, Nature, 317, 603604, 1985.

Otofuji, Y., T. Itaya, and T. Matsuda, Rapid rotation of southwest Japanpaleomagnetism and K-Ar ages of Miocene volcanic rocks of southwest Japan, Geophys. J. Int., 1991 (in Japanese with English Abstract).

Sawada, S., A. Toume, S. Kobayashi, H. Komuro, H. Kitagawa, and H. Murakami, Volcanic vent and feeder dikes from the Latest Miocene Tsuzurao Volcanic Rocks, Oki-Dogo, J. Geol. Soc. Japan, 105(4), pictorials, 1999 (in Japanese).

Tainosho, Y., K. Shibata, and S. Uchiumi, Granitic rocks in Dogo, Oki Islands, Shimane prefecture, Japan, J. Geol. Soc. Japan, 97, 53-60, 1991 (in Japanese with English abstract).

Tamaki, T., K. Suyehiro, J. Allan, J. C. Ingle, Jr., and A. Kenneth, Pisciotto, Tectonic systhesis and implications of Japan Sea ODP drilling, in Proc. ODP, Sci. Results, 127/128, edited by K. Tamaki, K. Suyehiro, J. Allan, M. McWilliams, et al., pp. 1333-1350, Ocean Drilling Program, College Station, TX, 1992.

Yamasaki, H., Ceozoic stratigraphy on the north of Sigo Bay, southern part of Oki-Dogo Island, Southwest Japan, J. Geol. Soc. Japan, 97, 917-930, 1991 (in Japanese with English abstract).

Yamasaki, H., The Dogo Group in the Oki Dogo Island, Southwest Japan and the South Oki Ridge, Mem. Geol. Soc. Japan, 37, 277-293, 1992 (in Japanese with English abstract).

Yamasaki, H. and Y. Ganzawa, Fission track ages of the Tertiary Kori and Yui Formations in Dogo, Oki Islands, west Japan, J. Geol. Soc. Japan, 95, 619-622, 1989 (in Japanese).

Yamasaki, H., M. Shitasue, and K. Takayasu, Re-examination of stratigraphic relationship between the Miocene Kori and Kumi Formations in Dogo, Oki Islands, West Japan, Earth Science, 45, 177-190, 1990 (in Japanese with English abstract).

Yamauchi, S. and A. Yoshitani, Tectonic movement in the progressive stage of the Green-Tuff basins-Taking the case of the Miocene series in the eastern part of Shimane Prefecture, western Japan-, J. Geol. Soc. Japan, 87, 711-724, 1981 (in Japanese with English abstract).

Yokota, M., Diatomaceous earth in Dogo, Oki Islands, Geol. Rept. Shimane Univ., 3, 139-144, 1984 (in Japanese with English abstract).

Yoshitani, A., T. Danhara, and H. Murakami, On the fission track age of Kori Formation belonging to Dogo Group distributed in Dogo Islands, $J$. Fac. Edu. Tottori Univ. Natural Science, 44, 91-101, 1995 (in Japanese with English abstract).

T. Kojima (e-mail: nd7403@mcs.ipe.ibaraki.ac.jp), M. Okada, H. Ohira, K. Tokieda, H. Komuro, and K. Amano 